\title{
PKM SISTEM INFORMASI PERJALANAN DINAS DI BALAI PENGKAJIAN DAN PENGEMBANGAN KOMUNIKASI DAN INFORMATIKA (BPPKI) MANADO
}

\author{
Olivia Kembuan \\ Jurusan PTIK, Fakultas Teknik, \\ Universitas Negeri Manado \\ lyve.kembuan@gmail.com
}

\begin{abstract}
Abstrak
Perjalanan Dinas merupakan salah satu proses bisnis yang biasanya dilaksanakan pada hampir setiap perusahaan atau instansi. Manfaat perjalanan dinas secara umum antara lain untuk menyelesaikan tugas-tugas kantor yang berkaitan atau berhubungan dengan kegiatan perusahaan. Perjalanan dinas sendiri sudah diatur dalam Peraturan Menteri Keuangan Nomor 37/PMK.02/2012, dan untuk melakukan perjalanan dinas harus berdasarkan dari namanya Surat Perintah Perjalanan Dinas (SPPD).

Sistem yang akan dikembangkan bertujuan untuk mengelola proses pembuatan surat tugas dan surat perintah perjalanan dinas dilanjutkan dengan persetujuan surat tugas dan surat perintah dinas kemudian pemasukan atau perhitungan biaya uang muka, pemasukan laporan dan persetujuan laporan dan yang terakhir pemasukan biaya perampungan.
\end{abstract}

Dalam perancangan aplikasi ini peneliti menggunakan metode Prototype.

Kata Kunci: Sistem Informasi, SPPD 


\section{PENDAHULUAN}

Perjalanan Dinas merupakan salah satu proses bisnis yang biasanya dilaksanakan pada hampir setiap perusahaan atau instansi. Manfaat perjalanan dinas secara umum antara lain untuk menyelesaikan tugas-tugas kantor yang berkaitan atau berhubungan dengan kegiatan perusahaan. Perjalanan dinas sendiri sudah diatur dalam Peraturan Menteri Keuangan Nomor 37/PMK.02/2012, dan untuk melakukan perjalanan dinas harus berdasarkan dari namanya Surat Perintah Perjalanan Dinas (SPPD).

Surat Perintah Perjalanan Dinas yaitu surat pengantar yang dibuat ketika karyawannya akan melakukan perjalanan dinas ke kota atau daerah tertentu. Saat ini, masih sama seperti pembuatan dan pengolahan jenis-jenis surat lain pada umumnya, dalam pembuatan dan pengolahan surat perintah perjalanan dinaspun masih menggunakan cara yang sederhana serta harus melalui proses pencatatan manual.

Dalam pembuatan dan pengolahan perjalanan dinas yang ada saat ini ditemui banyak kekurangan-kekurangan yang harus dihadapi, seperti harus dilakukannya pengeditan berulang-ulang setiap kali akan ada karyawan yang ditugaskan, sering terjadi kesalahan pengetikan data karyawan ataupun data surat, perhitungan biaya uang muka terkadang keliru serta cukup memakan waktu dan persetujuan surat yang masih dibatasi oleh waktu dan tempat. Kekurangan-kekurangan tersebut, mengakibatkan hal-hal yang tidak diinginkan terjadi, yaitu seperti banyaknya kertas yang terbuang, waktu pembuatan surat menjadi lebih lama, pembiayaan menjadi tidak optimal dan membuat keterlambatan penugasan.

BPPKI Manado adalah Balai yang bergerak pada bidang pengkajian dan pengembangan komunikasi dan informatika yang dinaungi langsung oleh KEMKOMINFO (Kementrian Komunikasi dan Informasi). Setiap hari balai ini tidak terlepas dari aktifitas yang berhubungan dengan perjalanan dinas, dikarenakan kantor ini mempunyai kerja rutin dalam melakukan survei di berbagai daerah yang dinaungi oleh kantor sendiri dan dalam pembuatan dan pengolahan perjalanan dinas dikantor BPPKI Manado masih menggunakan cara sederhana, sehingga tidak menunjukan kompleksitas dari banyaknya kegitan perjalananan dinas yang sering dilakukan.

\section{KAJIAN LITERATUR}

1. Sistem Informasi

Sistem Informasi adalah suatu sistem di dalam suatu organisasi yang mempertemukan kebutuhan pengolahan transaksi harian, mendukung operasi, bersifat manajerial dan kegiatan strategi dari suatu organisasi dan menyediakan pihak luar tertentu dengan laporan yang diperlukan [1]. 
2. Perjalanan Dinas

Perjalanan dinas adalah perjalanan yang dilakukan oleh pegawai suatu perusahaan yang berkaitan dengan tugas pekerjaan kedinasan. Tugas pekerjaan kedinasan merupakan tugas yang diberikan dengan kepentingan lembaga atau perusahaan yang bersangkutan. Perjalanan dinas dilakukan karna berbagai kepentingan, antara lain pelaksanaan pengawasan di kantor cabang atau perusahaan cabang, seminar, diklat, tender, janji temu, penjajakan kerjasama, menghadiri acara seremonial, kegiatan sosial dan lain-lain [2].

\section{Metode Prototype}

Menurut [3], dalam melakukan perancangan sistem yang akan dikembangkan dapat mengunakan metode prototype. Metode ini cocok digunakan untuk mengembangkan sebuah perangkat yang akan dikembangkan kembali. Metode ini dimulai dengan pengumpulan kebutuhan pengguna. Kemudian membuat sebuah rancangan kilat yang selanjutnya akan dievaluasi kembali sebelum diproduksi secara benar.

\section{METODE PELAKSANAAN}

\section{Metode Pengumpulan data}

Suatu penelitian yang baik selalu diawali metode-metode yang digunakan dalam setiap pengumpulan data. Metode untuk pengumpulan data yang digunakan dalam proses penelitian ini terbagi 5 (lima), yaitu :

- Pengamatan, pengamatan dilakukan secara langsung pada saat melakukan pembuatan sampai perampungan data perjalanan dinas di BPPKI Manado.

- Wawancara, pengambilan data dilakukan dengan wawancara. Pihak yang diwawancarai adalah kepala dan staf Tata Usaha BPPKI Manado.

- Studi kepustakaan, penelitian dilakukan berdasarkan data yang diperoleh dari teori-teori yang didapatkan dari jurnal dan buku penunjang yang berhubungan dengan topik yang diambil sebagai bahan perbandingan atau dasar pembahasan lanjut.

- Internet, sumber data dan informasi yang diperoleh dan didapat secara online yang berguna untuk menambah referensi dan sebagai perbandingan bagi penelitian kepustakaan dan dokumentasi serta literatur untuk mendapat data sekunder guna memperkuat argumentasi dan presentasi.

- Analisa data, data yang diperoleh selanjutnya dianalisis untuk mengembangkan sistem yang ada dengan tujuan memperoleh hasil yang lebih baik lagi.

\section{Metode Pengembangan Sistem}

Dalam perancangan ini penulis menggunakan metode Prototye. Metode Prototype yang digunakan memilik 5 tahapan, yaitu :

1. Komunikasi : dalam tahap ini peneliti akan melakukan analisis kebutuhan (analysis requitment) yaitu dengan tahapan mengadakan pengumpulan data dengan 
cara melakukan pertemuan dengan customer dalam hal ini yaitu Kepala, Kabag TU, PPK dan berbagai pihak yang terkait di BPPKI Manado.

2. Perencanaan Secara Cepat : dalam tahap ini peneliti akan melakukan perencanaan secara cepat sesuai dengan tahapan sebelumnya, dimana peneliti akan melakukan perencanaan mengenai tools dan jangka waktu yang diperlukan dalam pembuatan sistem (jadwal pembuatan sistem).

3. Pemodelan Perancangan Secara Cepat : dalam tahap ini syarat kebutuhan diterjemahkan ke sebuah perancangan sistem yang dapat diperkirakan sebelum dibuat coding. Untuk tahapan ini peneliti akan merancang sistem informasi perjalanan dinas yang didalamnya mencakup pemodelan bisnis, pemodelan data dan pemodelan proses. Untuk pemodelan proses peneliti akan menggunakan tools pemodelan UML (Unified Modelling Language).

4. Pembuatan Prototype : dalam tahap ini peneliti melakukan proses membuat kode. Peneliti akan menerjemahkan transaksi yang diminta oleh user. Setelah pengkodean selesai maka akan dilakukan pengujian terhadap sistem yang telah dibuat menggunakan metode pengujian black box testing.

5. Penyerahan Sistem : dalam tahap ini merupakan tahap final dalam pembuatan sistem. Setelah melakukan analisis, desain dan pengkodean maka sistem yang sudah jadi akan diserahkan kepada user, yang kemudian masih bisa di evaluasi dan diperbaiki kembali sesuai keingianan user sampai benar-benar sistem yang dibuat dapat digunakan.

\section{Bahan dan Alat}

Bahan dan alat yang digunakan dalam penelitian terdiri dari perangkat lunak (software) dan perangkat keras (hardware).

- Perangkat lunak (software)

- Sistem operasi windows

- Teks editor notepad++ v7.4.2

- Browser chrome

- xampp

- Perangkat keras (hardware)

- Memori RAM 4 Gb DDR3

- CPU Intel Core i5 $2.20 \mathrm{GHz}$

- Printer canon pixma MP237

\section{HASIL DAN PEMBAHASAN}

Pada bagian ini akan dibahas hasil penelitian dan pembahasan yang mencakup perancangan dan implementasi sistem informasi perjalanan dinas di BPPKI Manado. Penelitian dilakukan dengan mengacu pada tahap-tahap model pengembangan perangkat lunak Prototype. Tahapan yang telah dilakukan antara lain sebagai berikut :

\section{Komunikasi}


Pada tahap ini, peneliti melakukan identifikasi spesifikasi kebutuhan dengan wawancara langsung pada pengguna yang nanti akan menggunakan sistem ini. Adapun yang diwancarai oleh peneliti dalam tahapan ini diwakilkan oleh PPK yang juga selaku Kepala TU. Berdasarkan hasil wawancara, didapatkan beberapa kebutuhan yang harus dipenuhi oleh sistem yaitu :

1. Aktor

Pada system yang akan dibuat, actor yang harus terlibat yaitu : admin, tata usaha, kepala, pejabat pembuat komitmen, keuangan dan karyawan.

2. Manajemen Pengguna

Pada system yang akan dibuat, ada beberapa manajemen yang harus ada didalamnya yaitu : manajemen surat tugas, manajemen surat perintah dinas, manajemen biaya uang muka, manajemen biaya perampungan, manajemen laporan karyawan dan manajemen admin.

\section{Perencanaan Secara Cepat}

Pada tahap ini peneliti mendefinisikan kebutuhan tools yang akan digunakan untuk membuat sistem informasi perjalanan dinas beserta jangka waktu yang diperlukan. Tahapan ini dilakukan secara cepat dalam selang waktu pendek atau singkat.

\section{Pemodelan Perancangan Secara Cepat}

\section{Pemodelan Bisnis}

Dalam pemodelan bisnis akan dijelaskan bagaimana alur dari sistem yang akan dibuar dengan menggunakan flowchart bisnis yang dapat dilihat pada gambar 1 berikut.

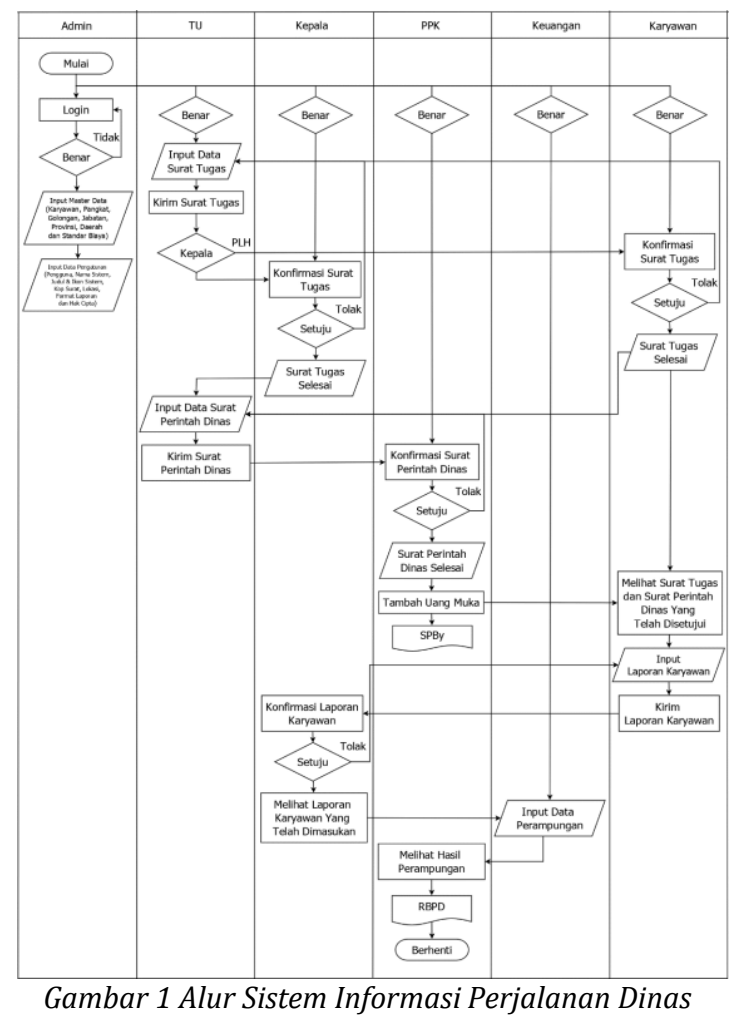

\section{Pemodelan Data}

Pemodelan data yang dibuat yaitu desain database. Desain Database merupakan rancangan struktur record yang berfungsi untuk mengetahui tabel-tabel yang berhubungan dalam program.

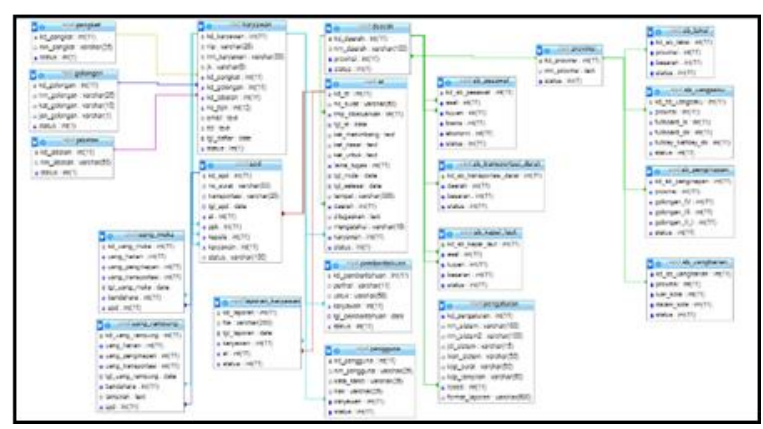

Gambar 2 Desain Database Sistem Informasi Perjalanan Dinas 


\section{Pemodelan Proses}

Dalam pemodelan proses peneliti akan mulai merancang sistem perjalanan dinas dengan teknik desain sistem menggunakan UML (Unified Modelling Language). Adapun hasil pemodelan proses menggunakan UML dengan bentuk use case diagram.

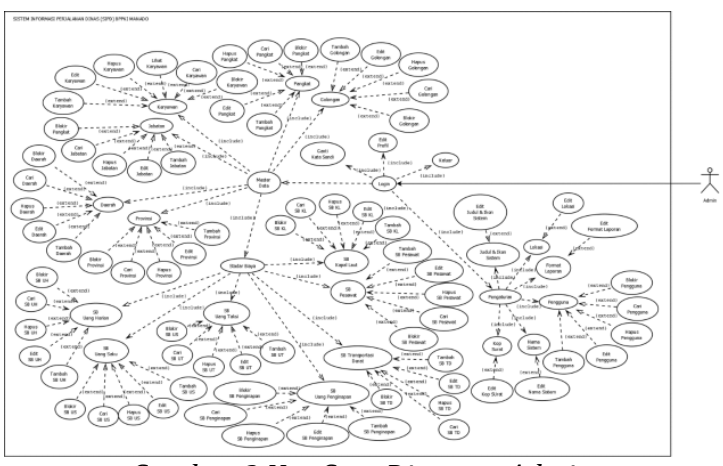

Gambar 3 Use Case Diagram Admin

\section{Pembuatan Prototype}

Pada tahap ini peneiliti akan melakukan penulisan kode kedalam program sesuai dengan tahap perancangan yang telah dibuat dan tools yang telah ditentukan sebelumnya, kemudian akan dilakukan pengujian sistem untuk mengetahui apakah sistem tersebut masih ditemukan kesalahan sehingga harus diperbaiki atau tidak.

\begin{tabular}{c|llll} 
NO & \multicolumn{1}{c}{ FUNGSI } & \multicolumn{2}{c}{ PERNYATAAN } & HASIL \\
\hline $\mathbf{1}$ & Login & Fungsi & Untuk & Sesuai \\
& & Melakukan Login & \\
$\mathbf{2}$ & Tambah & Fungsi & Menambah & Sesuai \\
& Karyawan & Data Karyawan & \\
& Tambah & Fungsi & Menambah & Sesuai \\
& Pengguna & Data Pengguna & \\
& Tambah Surat & Fungsi & Menambah & Sesuai
\end{tabular}

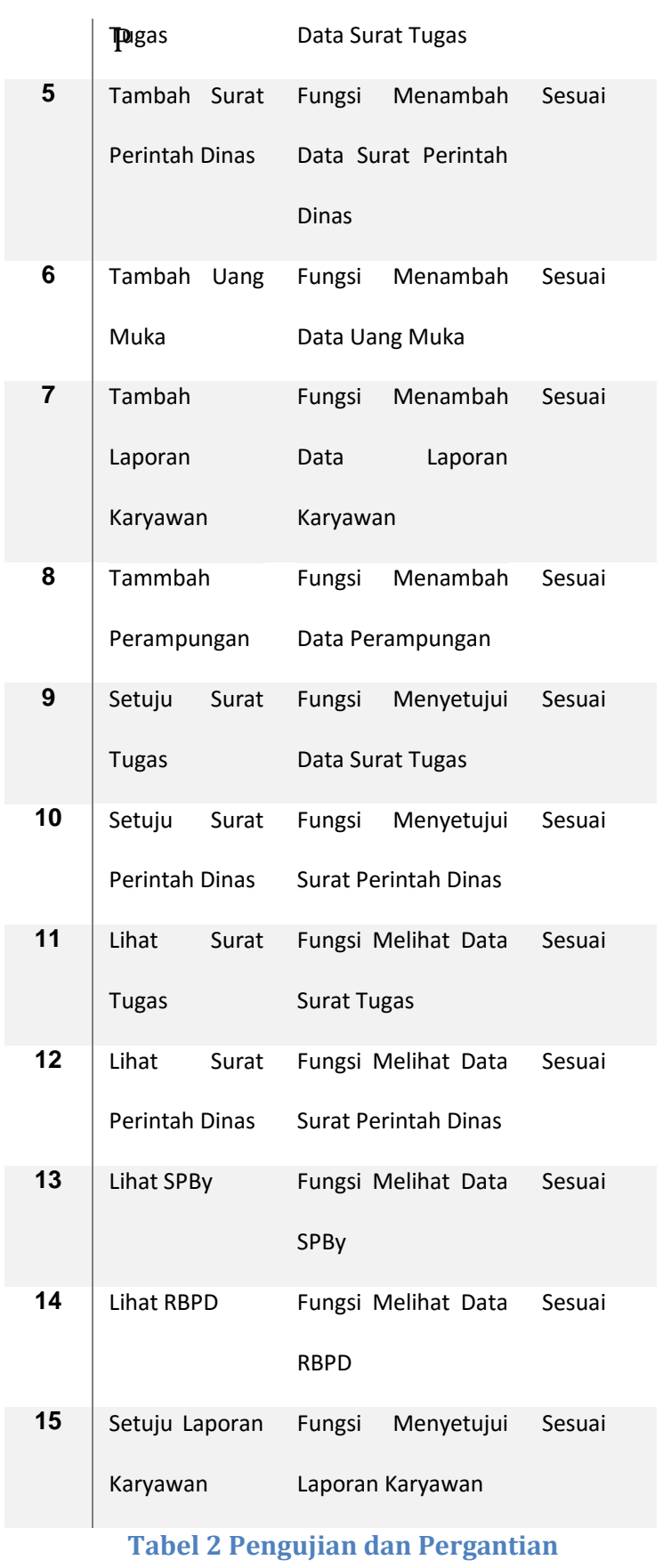

Selain melakukan pengujian pengujian black box, peneliti juga melakukan pengujian kuesioner untuk mengetahui apakah sistem ini bisa memberikan solusi erhadap permasalahan dan sesuai dengan kebutuhan yang ada maka dilakukan voting untuk menilai apakah solusi dapat terselesaikan dan sesuai kebutuhan. 


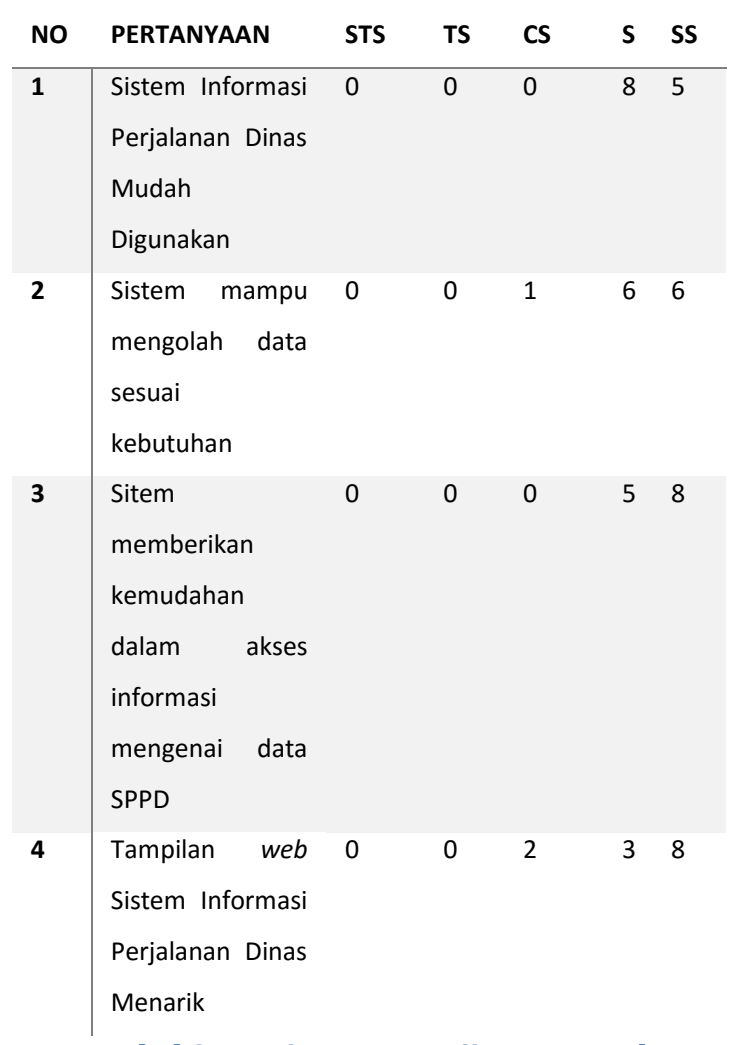

Tabel 3 Kuesioner Pengujian Responden Ket :

$\begin{array}{ll}\text { TS } & \text { : Sangat Tidak Setuju } \\ \text { S } & \text { : Tidak Setuju } \\ \text { S } & \text { : Cukup Setuju } \\ & \text { : Setuju } \\ \text { S } & \text { : Sangat Setuju }\end{array}$

Hasil pengujian untuk pernyataan 1 menunjukan sebanyak 61,54\% responden menjawab setuju dan 38,46\% responden menjawab sangat setuju. Jadi disimpulkan bahwa sistem informasi perjalanan dinas mudah digunakan.

Hasil pengujian untuk pernyataan 2 menunjukan sebanyak 7,69\% responden menjawab cukup setuju, 46,15\% responden menjawab setuju dan 46,15\% responden menjawab sangat setuju. Jadi disimpulkan bahwa sistem mampu mengolah data sesuai kebutuhan.

Hasil pengujian untuk pernyataan 3 menunjukan sebanyak 38,46\% responden menjawab setuju dan 61,54\% responden menjawab sangat setuju. Jadi disimpulkan bahwa sistem dapat memberikan kemudahan dalam akses informasi mengenai data SPPD.

Hasil pengujian untuk pernyataan 4 menunjukan sebanyak 15,38\% responden menjawab cukup setuju, 23,08\% responden menjawab setuju dan 61,54\% responden menjawab sangat setuju. Jadi disimpulkan bahwa tampilan web sistem informasi perjalanan dinas menarik.

\section{Tahap Penyerahan Sistem}

${ }^{S}$ Pada tahap ini sistem yang telah melewati tahap pengujian atau yang sudah selesaf, siap untuk diimplementasikan di Kantos BPPKI Manado.

s Berikut adalah implementasi user interface (UI) yang telah dibuat sesuai dengan pengkodean proses dalam tahapan Prototype.

- Halaman Login

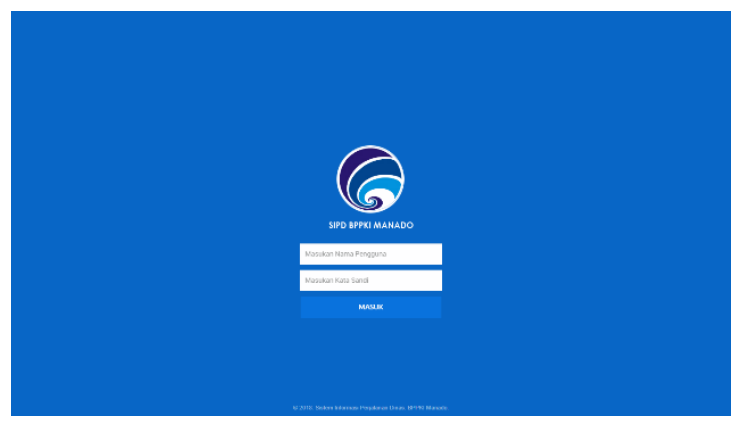

Gambar 9 Halaman Login Sistem 
- Halaman Beranda Admin

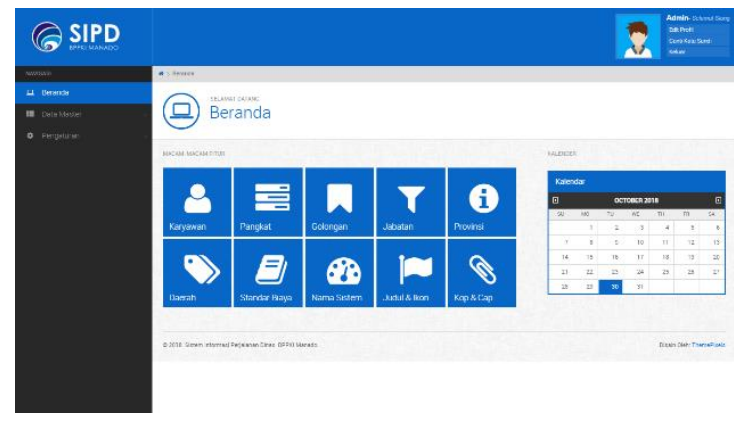

Gambar 10 Halaman Beranda Admin

- Halaman Tambah Uang Muka

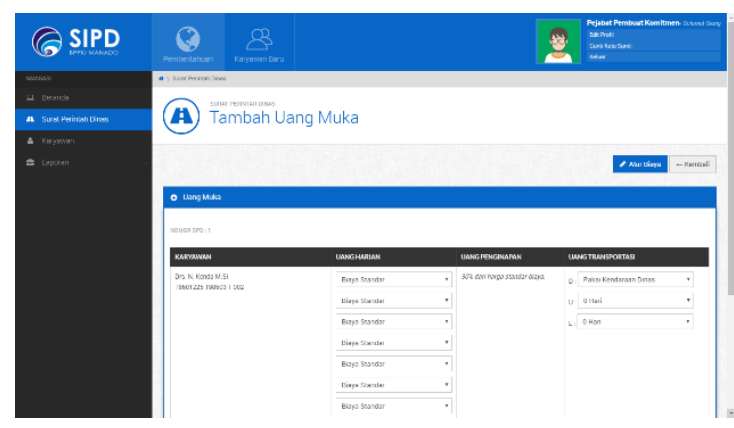

Gambar 11 Halaman Tambah Uang Muka

- Halam Lihat Perampungan

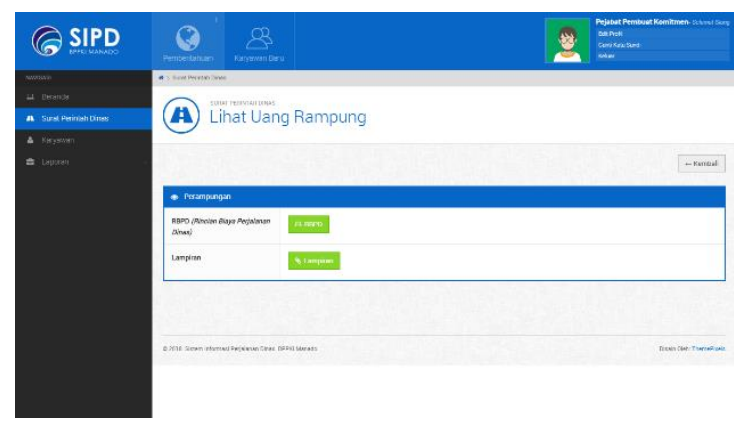

Gambar 12 Halaman Lihat Perampungan

\section{KESIMPULAN DAN SARAN}

\section{Kesimpulan}

Berdasarkan hasil penelitian dan pengujian sistem yang telah dibuat dan dibahas, maka dapat diambil kesimpulan antara lain: a. Dapat memudahkan karyawan Tata Usaha (TU) dalam membuat surat tugas dan surat perintah dinas.

b. Persetujuan surat tugas maupun surat perintah dinas menjadi lebih mudah.

c. Dapat memudahkan Pejabat Pembuat Komitmen (PPK) dalam melakukan estimasi uang muka karena ada bantuan estimasi dari sistem.

d. Pembuatan Surat Perintah Bayar (SPBy) dan Rincian Biaya Perjalanan Dinas (RBPD) menjadi lebih mudah.

\section{Saran}

Berdasarkan kesimpulan di atas, maka peneliti dapat memberikan saransaran yang kiranya dapat membantu penelitian dan pengembangan sistem ujian online ini di masa yang akan datang. Saransaran peneliti dalam penelitian ini adalah sebagai berikut:

a. Diharapkan administrator secara terus menerus meng-update dan memelihara website agar tetap bisa digunakan secara berkelelanjutan.

b. Penggunaan ilmu pengetahuan dan teknologi hendaknya lebih ditingkatkan lagi dan diikuti perkembangannya, untuk meningkatkan sumber-sumber yang ada dimasa mendatang.

c. Penelitian ini bisa digunakan sebagai kajian pustaka bagi pembaca atau 
referensi bagi peneliti selanjutnya, sistem ini masih jauh dari sempurna, oleh karena itu penulis menyarankan agar sistem ini dikembangkan oleh peneliti selanjutnya.

\section{KEPUSTAKAAN}

A. S. Nugroho, Analisis dan Perancangan Sistem Informasi, Yogyakarta: Trans Tekno, 2017.

\author{
F. Sedianingsih, Teori dan Praktik \\ Administrasi Kesekretariatan., Jakarta: \\ Kencana, 2010, p. 4. \\ P. S. Pressman Roger, Rekayasa Perangkat \\ Lunak (Pendekatan Praktisi) Edisi 7 : Buku \\ 1, Yogyakarta: Andi, 2012.
}


Jurnal ABDIMAS, Vol. 12, No. 2, Agustus 2019

ISSN: 1979-0953 | e-ISSN: 2598-6066 